\title{
GENDER BUDGETING- AN ECONOMIC INITIATIVE FOR WOMEN EMPOWERMENT
}

\author{
KUMAR. S. P
}

Assistant Professor, Department of Economics, Sree Narayana College, Varkala, Sivagiri, India

\begin{abstract}
There is no denial of the fact that in spite of all the progress that had taken place during the 21st century, women continued to remain a marginalized section in many parts of the globe. It was only recently that there was a paradigm shift to strengthen the actions and outcome to achieve the desired goal of gender equity. The greatest effort in this context is that of the introduction of Gender Budgeting as a means of linking the social with the economic within an overall policy framework. So far the government is able to allocate only a small portion of the overall budget outlay towards various women specific programmes, a ray of hope is there for doing something better in future.

KEYWORDS: Spite of all the Progress \& Something Better in Future
\end{abstract}

Received: Jan 01, 2018; Accepted: Jan 22, 2018; Published: Feb 05, 2018; Paper Id.: IJESRFEB20189

\section{INTRODUCTION}

Gender budget initiatives use gender analysis to evaluate government budget impact on females and males. It pinpoints how budgets are discriminatory in gender and other social dimensions. According to the Report of the Expert Groups constituted to review the classification system for government transactions, Ministry of Finance, Government of India (2004) “ Gender budgeting refers to presentation of budgetary data in a manner so that the gender sensitivities of the budgetary allocations are clearly high lightened. It envisages higher budgetary allocations not only to women specific programs, but also to quantify pro-women allocations in the composite or gender neutral programmes under various departments". The above definition clearly indicates Gender Budget analysis is essential to understand what extend a budget addresses gender and related issues and it is quickly becoming a tool for managing critical governance issues and for assessing the impact of public policies on women. Depending on national/regional/local circumstances, gender budgeting initiatives should take all steps of the budgeting process into account and promote gender budgeting throughout the process, including planning, preparation, implementation, audit and evaluation.

\section{Tools and Method for Gender Budgeting}

Economists have developed a range of tools and methods for integrating gender into budgets. Following are the major tools of gender budgeting process:

- Gender based inequality analysis

- Gender aware policy appraisal

- Gender disaggregated beneficiary assessment analysis 
- Gender disaggregated public expenditure benefit incidence analysis

- Gender disaggregated analysis of the impact of budget on time use

- Gender aware budget statement and

- Gender - disaggregated tax incidence analysis.

The choice of tools ultimately depends upon the availability of the assets necessary for a gender budget analysis. Methodologies used in the analysis of Gender Budgeting are identified in three categories. They are:

- $\quad$ Expenditure on Women Specific Scheme (WSS).

- $\quad$ Pro - Women Allocations ( PWS )

- Mainstream public expenditure that have a gender- differential impact.

Total women's share is defined as a sum of WSS and PWS for the different needs and is calculated with respect to

- $\quad$ State budget outlay

- Total outlay on WSS and PWS of the state and central government for the important needs identified.

- Total plan and non-plan outlays of the state and central govt. on WSS and PWS for the different needs

- Total state's outlay on WSS and PWS of the state govt. for the important needs

- Total of state's plan and non- plan outlay on WSS and PWS.

\section{Gender Budgeting in Kerala}

Gender budget looks at how public expenditure takes into consideration the differential needs of men and women and plan allocations so that these needs are met. To do this, gender disaggregated data and informationis essential. In the absence of such a data, it is difficult to evaluate whether budget allocations are addressing needs. As far as our knowledge goes, there is no such comprehensive data collection exercise at the state level to understand the status of women in Kerala, their position in the social, economic, political and cultural life of the state. Some studies were undertaken only at the micro level (Panchayats) and these were done to assist local planning. Compiling such information itself will give trends regarding women's status and position.

The state government has taken certain initiatives in terms of women targeted schemes (gender responsive) through Flagship programmes in the $11^{\text {th }}$ plan. These are the gender awareness programmes including the implementation of the protection of women from domestic violence act and the flagship program for finishing school for women (to enhance employability of women through skill training).

In the budget of 2010-11, gender audit of only the above two programmes was made, and thereby more funds were allocated. The total outlay earmarked for women accounted for only $5.5 \%$ of the total State budget outlay in $2008-09$, which increased to $11.2 \%$ in $2015-16$. 
Table 1: State Budget Allocation for Schemes Solely for the Benefit of Women (100\%)

\begin{tabular}{|c|c|c|}
\hline Year & Budget Allocation (Rs. In crores) & \% To Total Allocation \\
\hline $2008-2009$ & 318.69 & 5.5 \\
\hline $2009-2010$ & 367.69 & 5.6 \\
\hline $2010-2011$ & 620.97 & 8.5 \\
\hline $2011-2012$ & 875.36 & 9.2 \\
\hline $2012-2013$ & 1006.21 & 10.0 \\
\hline $2013-2014$ & 1020.01 & 10.2 \\
\hline $2014-2015$ & 2100.00 & 11.1 \\
\hline $2015-2016$ & 2151.16 & 11.2 \\
\hline
\end{tabular}

Source: Budge Document 2016

Table 1 shows an increasing trend of budget allocation to WSS. Percentage rate of growth of budget allocation also showing increased trend but it is still around ten percentages. It indicates with a population percentage of more than fifty gets lower budget allocation. The following table shows the allocations solely for women:

Table: 2 Allocations in the Budget of 2012-2013

\begin{tabular}{|l|c|}
\hline \multicolumn{1}{|c|}{ Classifications } & Amount (Rs.in crore) \\
\hline Target Schemes for Women (100\% allocation) & 1006.21 \\
\hline Pro women schemes (50-99 \%) & 248.57 \\
\hline Pro-women schemes ( 30-49 \%) & 25.56 \\
\hline Targeted schemes for women (Less 30 \%) & 15.13 \\
\hline Gender neutral Schemes & 513.53 \\
\hline Total & $\mathbf{1 8 0 9 . 0 0}$ \\
\hline
\end{tabular}

A total of 1809 crores is mentioned in the budget speech of 2012-13 as earmarked solely for women. But while going through the budget documents only $56 \%$ has been allocated for women alone (100\%). The rest is divided across various departments and are for schemes indirectly benefitting women. Some examples are increased welfare pensions, urban employment guarantee scheme, income support scheme for traditional sectors (coir, cashew, bamboo mats weaving etc where mostly women work), fuel efficient firewood stoves, assistance for marriage and treatment, interest support to Kudumbasreeetc.

\section{LIMITATIONS OF GENDER BUDGET FORMULATION IN KERALA}

While undertaking a gender budget analysis of the state budget of Kerala, the difficulties faced are:

- A difficult task is to understand the logic of allocation and expenditure on pro-women and gender neutral schemes in the budget and its relation to gender disaggregated data.

- In the annual plan proposals of Kerala budget since 2008-09, formats and schedules of budgetary procedures and reporting systems include the amount earmarked for women (WC). But how such percentages are arrived at by the concerned departments is anybody's imagination.

- Another issue is the need to do performance audit; ie, conduct review to analyse the financial and physical achievements and identify the constraints in achieving the targets. Such a process will reveal the gaps in delivery 
of services, the lack of needed infrastructure, the lack of gender sensitivity of the personnel who are implementing the programmes. Another aspect of performance audit is carrying out reality check by evaluating programme interventions, incidences of benefit, identifying impact indicators like the change in the condition and position of women before and after a programme is implemented. A third aspect is compiling a trend analysis of expenses, output indicators and impact indicators.

\section{CONCLUSIONS}

Steps may be taken by authorities to establish a detailed gender disaggregated data base in all departments. Further, it may ensure that programmes and implementing mechanisms have inbuilt provisions for gender disaggregated data collection. Moreover, overall outlays earmarked for women as well as the share of women specific schemes in Kerala budget need to be stepped up significantly in order to address the deprivations confronting women in various sectors. Appropriate policies and matching outlays are to be made for enhancing the enrollment of girl students in the technical education sector. Above all gender issues have to be integrated into the documents of the Ministry of Finance and key ministries and departments and gender committees in each department may be constituted for the implementation, monitoring and for making the outcome and impact assessment of schemes.

\section{REFERENCES}

1. Acharya,Meena (2002): "Gender Budget Audit in Nepal", Submitted by Institute for Integrated Development Studies(IIDS), Nepal to UNIFEM/UNDP

2. Banerjee, N (2002): "What is Gender Budgeting?" Public Policies from Women Perspective in the Indian Context, UNIFEM, 2002.

3. Rekha U. Menon \& V. P Sukumaran, Urbanization and Women Empowerment an Overview, International Journal of Human Resource Management and Research (IJHRMR), Volume 5, Issue 2, March - April 2015, pp. 35-40

4. Chakraborty,Lekha(2008): "Institutional Mechanism for Gender Budgeting : Prior Evidence from India", Gender Mainstreming,2008.

5. Economic Review,(2011-2015), Kerala State Planning Board, Trivandrum.

6. Ministry of Finance Government of India, (2004): " Report of the Expert Group Constituted to Review the Classical System for Government Transactions”, July, 20014, New Delhi.

7. Sangeeta Sharma et al., Regional Rural Banks, Microfinance and Women Empowerment, International Journal of Agricultural Science and Research (IJASR), Volume 7, Issue 4, July - August 2017, pp. 251-256

8. SeetaPrabhu,KandKalyaniMenon(2001): “The Budget: A Quick Look Through a Gender Lense”, Economic and Political Weekly,Vol. XXXVI No.14-15, April 7,2001. 